\title{
Gustav-Steinmann-Medal 2011: A tribute to A. M. Celâl Şengör
}

\section{Daniel Bernoulli}

Published online: 29 November 2011

(C) Springer-Verlag 2011

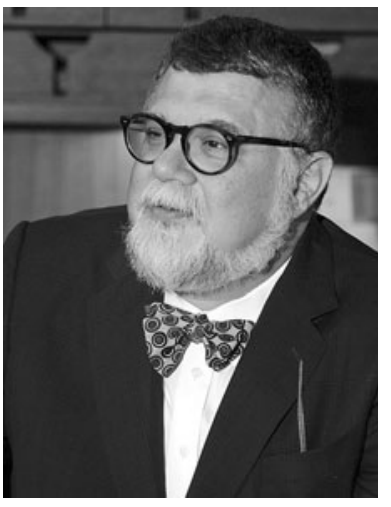

A. M. Celâl Şengör receives the Gustav-Steinmann-Medal 2010 for his fundamental contributions to the tectonic evolution of Asia and to the history of geology.

Celâl Şengör is one of the foremost experts of the geology of Asia, an area he has investigated over decades. The central theme of his research is the reconstruction of the plate movements from the Palaeozoic to the present day that led to the existing collage of continental fragments, island arcs, and relics of the different branches of the Palaeozoic and Mesozoic Tethyan oceans or, in his own words, the question 'How many wives did Okeanos have?' By his research, Şengör has revived Argand's Tectonique de l'Asie. Indeed, his work covers almost the entire area from the sutures of south-western China across Tibet to Iran and Turkey. In particular, the discovery of Cimmerian continental fragments and the reconstruction of the accretion of Gondwanian microplates to Asia was a milestone.

D. Bernoulli $(\square)$

Geologisch-Paläontologisches Institut der Universität Basel,

Bernoullistrasse 32, 4056 Basel, Switzerland

e-mail: Daniel.Bernoulli@unibas.ch
Other important publications treat in an exemplary fashion fundamental geodynamic processes such as the formation of accretionary wedges and mélanges, formation of rift basins and the role of intracontinental 'epirogenetic' movements.

Ali Mehmet Celâl Şengör was born in 1955 in Istanbul where he also went to school. After finishing high-school in 1973, he went to Munich and Berlin for a year, learning the German language at the Goethe Institut. From there, he moved to the University of Houston where he spent 2 years. From 1976 to 1982, he studied at the State University of New York at Albany, then a hotbed of the New Global Tectonics, obtaining his B. Sc., M. Sc. and Ph. D. degrees. His doctoral dissertation under the supervision of John F. Dewey brought him to the high Alps where he investigated the tectonics of the Albula zone, a complex area within the Austroalpine nappe system in eastern Switzerland. In the Geology Institute of the Swiss Federal Institute of Technology, he made many life-long friends, last but not least Rudolf Trümpy. From 1981 to 1986, he was Lecturer and then Reader of Geology at the Istanbul Technical University. Since 1992, he is Professor of Geology at this Institution.

Celâl lives true scholarship with great passion. He is a brilliant historian of science and a true homme de lettre. Once I told him, probably slightly irritated by his encyclopaedic explanations: 'Celâl, you are a man of the nineteenth century'. He replied: 'You could not have paid me a greater compliment'. Indeed, all his work is rooted in the tradition of our science and is committed to the historical heritage of geology in the widest sense. With the help of his prodigious memory and his wide cultural approach, he is rendering the observations of the authors of the nineteenth and early twentieth century a living source of information extracting the elements relevant for a 
coherent interpretation in a modern context. As a boy, he was led to geology by reading Jules Verne's books Voyage au centre de la Terre and on the journeys of the Nautilus. These books stimulated his curiosity and were at the beginning of lifelong reading and learning, and books have remained his permanent passion. Jorge Luis Borges once said 'I always imagined the paradise as a sort of library', and indeed, Celâl created such a paradise in Istanbul, a marvellous library covering the entire history of geology from Archbishop Ussher and Steno to Suess, Wegener and Argand, his heroes. Here, he works, probably in the middle of the night, in his own universe that resembles Captain Nemo's library on the Nautilus; however, recognizing that he is in a privileged position in being able to assemble this gem, Celâl generously shares it with his many visitors who use it as a rich quarry for their own work.

Celâl is not only an outstanding geologist, an enthusiastic scientist and homme de lettre, but also a responsible citoyen. He has done a lot for the advancement of modern geology in Turkey and has shown much civilian courage in his fight for the freedom of thought and against bigotry and obscurantism, whereby, as in all his undertakings, he is not a friend of understatement.

Celâl Şengör has earned much recognition for his scientific achievements; he is a member of several academies and many learned societies; he is among a select group of Turkish scientists who have achieved international renown. His proven record of scholarly research and leadership has been the driving force taking Earth Sciences in Turkey out of their regional, domestic audience onto the international scene. His long-standing connections with the Geologische Vereinigung have included service as Vice President and, last but not least, as the initiator of our publication Milestones in Geosciences. With the bestowal of the GustavSteinmann-Medal, the Geologische Vereinigung honours Celâl Şengör as an outstanding geologist of his generation. 